\title{
STUDENTS' KNOWLEDGE ABOUT SIGNS AND SYMPTOMS FOR PATIENT WITH COVID-19 IN NURSING COLLEGE AT UNIVERSITY OF MOSUL
}

\author{
Ali Mohammed Fathi ${ }^{1}$, Ali Ismael Sulaiman ${ }^{2}$, Saad Hussein Murad ${ }^{3}$ * \\ 1. Department of clinical nursing, College of Nursing, University of Mosul, City of Mosul, Iraq; \\ 2. Department of clinical nursing, College of Nursing, University of Mosul, City of Mosul, Iraq; \\ 3. Department of clinical nursing, College of Nursing, University of Mosul, City of Mosul, Iraq.
}

Corresponding author: Ali Mohammed Fathi

Email: Ali.m.fathi@uomosul.edu.iq

ORCID

\section{ABSTRACT}

The initial COVID-19 clinical manifestations are similar to all viral pneumonia species, with varying severity degree. World Health Organization (WHO) revealed that 80\% of patients with COVID-19 demonstrated gentle or no clinical intercession and $20 \%$ of the influenced cases experienced serious sicknesses, for example, shortness of breathing and various organ disappointments. It has been accounted for that $2 \%$ of severe cases can be deadly. furthermore, it is analyzed and founded through a research facility test that contamination can prompt intense respiratory issues especially among older patients and individuals with fundamental ceaseless ailments. Notwithstanding, some tainted individuals are transporters of the infection without side effects while others may experience the ill effects of a mellow disease and recuperate effectively. To assess of students' knowledge toward Sign and Symptoms of Patients with Covid-19 in Nursing College at University of Mosul. To achieve the aim of these study, Across - sectional design was used with the application of structured questionnaire and this study is conducted in Nursing College at University of Mosul. Simple random sampling technique was conducted using a survey instrument to obtain responses from students includes 218 students from all stages of collage. The data were analyzed by using SPSS version 24 . Result of the study indicates that (42.7\%) from students at age (20-24) Also, the results show (41.7\%) of students were from fourth stage of collage. With regard to the gender (65.1\%) of them were females. Also, the result shows statistically significant differences in the students' knowledge toward the signs and symptoms of COVID-19. It was evident from the study that majority of the students have inadequate knowledge regarding signs and symptoms of COVID_19 also shows that there were no significant differences between students' knowledge and stage of education.

Keywords: Students, knowledge, Signs, Symptoms, COVID-19

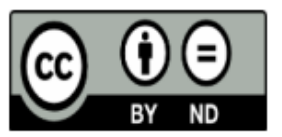

This work is licensed under a Creative Commons Attribution Non-Commercial 4.0 International License.

Received: 01 October 2021, Accepted: 22 September 2021, Available online: 20 January 2022 


\section{INTRODUCTION}

Corona viruses are a huge gathering of infections regular all through society. Truly, proof has demonstrated that the infection is sent by feathered, warm-blooded animals and affect people especially defenseless against disease (Sundarasen et al., 2020).

Past episodes of Covid was detailed firstly in December 2019, which is the momentum sickness in questions which caused coronavirus outbreak worldwide COVID-19 (WHO, 2019).

Coronavirus spreads among individuals through close contact (around six feet) with infected individuals through the respiratory framework (hacking or wheezing) or is sent by contacting a surface or something in which the infection is discovered (Sauer, 2020).

For individuals who are not high-risk contacts, the period of communicability is 48 hours prior to the onset of any symptom. For these individuals, the period of self-isolation is 10 days from the development of any COVID-19 specific symptom or until they receive a negative test result and symptoms have been resolving for 24 hours if they are fully vaccinated or previously positive (CDC, 2020).

The most common signs and symptoms of COVID19 and which require self-isolation immediately include, fever (temperature of $37.8^{\circ} \mathrm{C}$ or greater), chills, cough (continuous, more than usual), croup (barking cough), shortness of breath (dyspnea), and olfactory or taste disorder such as loss of smell and taste (Alrasheedy,2021).

Other symptoms of COVID-19 which differs among individuals include, sore throat, rhinorrhea (runny nose), nasal congestion (stuffy nose), abdominal pain that is persistent or on going, unusual headache, decreased or lack of appetite (Aylie, Mekonen \& Mekuria, 2020).

As of now, there is no particular antiviral therapy and preventive antibody; Medical therapies are restricted to steady measures pointed toward mitigating side effects and the utilization of examination medications (Carlos et al., 2020)

Along these lines, applying a preventive measure to control COVID-19 contamination is a significant intercession. This is finished by washing hands with cleanser and water, by face covers (CDC, 2019).

\section{METHOD}

A descriptive study was carried out at the nursing college in Mosul University from period of 20th April / 2021 till 1st July / 2021. A questionnaire was constructed and provided for students which consist of two parts. The first part concerns the demographic data while the second part related to the students' knowledge toward Sign and Symptoms of Patients with Covid-19 in Nursing College at University of Mosul and the samples selected by simple random sampling to be included in the study, the researcher selects (218) students from the nursing college. The researchers using SPSS (Version 26) in statically analysis. 


\section{RESULTS}

Table 1. Self-Administered Questionnaire Sheet Related to Demographic Characteristics of students. No. $=218$.

\begin{tabular}{ccccccc}
\hline Variables & Groups & Study & & C.S. \\
P-value
\end{tabular}

Freq. $=$ Frequencies, $\%=$ Percentages, C.S.: Comparison Significant with $\chi 2$-test, $\mathrm{P}=\mathrm{P}$-value, H.S.: Highly Significant at $\mathrm{P}<0.01$.

Table 2. Mean of score for students' knowledge s toward signs and symptoms of COVID-19.

\begin{tabular}{|c|c|c|c|c|c|c|c|c|c|c|}
\hline \multirow{2}{*}{ Questions } & \multicolumn{2}{|c|}{ Yes } & \multicolumn{2}{|c|}{ May be } & \multicolumn{2}{|c|}{ Some time } & \multicolumn{2}{|c|}{ No } & \multirow[b]{2}{*}{ Sig. } & \multirow[b]{2}{*}{ MOS } \\
\hline & $\mathbf{F}$ & $\%$ & $\mathbf{F}$ & $\%$ & $\mathbf{F}$ & $\%$ & $\mathbf{F}$ & $\%$ & & \\
\hline $\begin{array}{l}\text { The patient has fever and } \\
\text { chill }\end{array}$ & 127 & 58.3 & 57 & 26.1 & 12 & 5.5 & 20 & 9.2 & 3.0 & MS \\
\hline The patient has sore throat & 94 & 43.1 & 111 & 50.9 & 11 & 5.0 & 2 & 0.9 & 3.3 & HS \\
\hline $\begin{array}{l}\text { The patient loss his } \\
\text { conscious }\end{array}$ & 88 & 40.4 & 64 & 29.4 & 39 & 17.9 & 27 & 12.4 & 3.1 & MS \\
\hline $\begin{array}{l}\text { The patient has muscle } \\
\text { aches }\end{array}$ & 126 & 57.8 & 42 & 19.3 & 16 & 7.3 & 34 & 15.6 & 3.1 & MS \\
\hline $\begin{array}{l}\text { The patient complains from } \\
\text { weight loss }\end{array}$ & 67 & 30.7 & 57 & 26.1 & 55 & 25.2 & 39 & 17.9 & 2.6 & MS \\
\hline The patient has constipation & 55 & 25.2 & 17 & 7.8 & 27 & 12.4 & 119 & 54.6 & 2.0 & LS \\
\hline $\begin{array}{l}\text { The patient has nasal } \\
\text { congestion }\end{array}$ & 44 & 20.2 & 28 & 12.8 & 22 & 10.1 & 124 & 56.9 & 1.9 & LS \\
\hline $\begin{array}{l}\text { The patient has loss of taste } \\
\text { and smell }\end{array}$ & 73 & 33.5 & 72 & 33.0 & 62 & 28.4 & 11 & 5.0 & 2.9 & MS \\
\hline The patient has headache & 55 & 25.2 & 13 & 6.0 & 44 & 20.2 & 106 & 48.6 & 2.0 & LS \\
\hline $\begin{array}{l}\text { The patient has shortness of } \\
\text { breathing }\end{array}$ & 26 & 11.9 & 67 & 30.7 & 36 & 16.6 & 89 & 40.8 & 2.1 & LS \\
\hline
\end{tabular}


Table 3. One-way analysis of variance for the different students' knowledge and age.

\begin{tabular}{ccccc}
\hline Categories & S.O.V & S S & M S & F.Obs \\
students' & Between Groups & 92986.494 & 30995.498 & 625.534 \\
knowledge & Within Groups & 10603.800 & & HS \\
& Total & $\mathbf{1 0 3 5 9 0 . 2 9 4}$ & 49.550 & \\
\hline
\end{tabular}

${ }^{*} \mathrm{Df}=217$

Table 4. One-way analysis of variance for the difference Students knowledge and stage of Education.

\begin{tabular}{ccccc}
\hline Categories & S.O.V & S S & M S & F.Obs \\
student & Between Groups & 1859.645 & 619.882 & \\
knowledge & Within Groups & 101730.648 & & 0.274 \\
& Total & 103590.294 & 475.377 & NS \\
\hline
\end{tabular}

${ }^{*} \mathrm{Df}=217$

Table 5. T-test for comparison for the different students' knowledge and gender.

\begin{tabular}{ccccccc}
\hline Categories & Sex & No. & $\mathbf{X}$ & S.D & T.obs & P $\leq 0.05$ \\
$\begin{array}{c}\text { student } \\
\text { knowledge }\end{array}$ & Male & 76 & 72.5395 & 22.43476 & 0.026 & $\mathrm{~S}$ \\
\hline Ff $=38$ & 142 & 72.9225 & 21.60807 & & \\
\hline
\end{tabular}

\section{DISCUSSION}

Now, COVID-19 is the subject of globally debate in social media, among the public, health care workers, and patients. With the current increase in COVID-19 transmission that has raised tensions for everyone, including health and health system officials. For this reason, adequate knowledge of healthcare professionals can help contain the epidemic by preventing and controlling COVID-19 during a global epidemic, which will enhance the physical and mental health of individuals (Abdullah \& Allen, 2016).

Table (1): presented the demographic characteristics of the students which indicates that $(42.7 \%)$ from students at age $(20-24)$ the explanation of this result related for system in our country the students usually admission to the collage at age 18 years. Also, the results show $(41.7 \%)$ from students were from fourth stage of collage. With regard to the gender $(65.1 \%)$ of them were females, this result is supported by (Alrasheedy et al., 2021) they find in their study the mean age of the participants was $22.5 \pm 1.70$. and the majority of the participants were females $(n=143 ; 61.64 \%)$.

Table (2): This table shows most of the students have poor knowledge about signs and symptoms while others have moderate knowledge. This result is agreement with (Tice et al., 2016) that find the participants had poor knowledge about SARS symptoms.

Table (3) This table shows that there were High significant differences between students' knowledge and age at $P$ value $\leq 0.05$. This result explanation by the knowledge and expert increase with age this study supported (Khan et al., 2014) which show high significant a positive perception of COVID-19.

Table (4) This table shows that there were no significant differences between students' knowledge and stage of education. and age at $\mathrm{P}$ value $\leq 0.05$.

Table (5) this table shows that there were significant differences between students' knowledge, and gender at $P$ value $\leq 0.05$.

\section{CONCLUSIONS}

According to the study student's total knowledge about signs and symptoms of Covid-19 was accept. And there are high statistical correlation of the age with all the study parts, also the nonstatistical correlation with all the study parts and their level of education, but there is found statistical correlation of gender with all the study parts.

\section{ETHICAL CONSIDERATIONS COMPLIANCE WITH ETHICAL GUIDELINES}

This study was completed from the coolege of nursing, University of Mosul, Iraq. The participants were informed about the research's purpose and ensured anonymity and confidentiality of the information. A written informed, voluntary participation consent was obtained from each participant.

\section{FUNDING}

This research did not receive any grant from 
funding agencies in the public, commercial, or non-profit sectors.

\section{AUTHOR'S CONTRIBUTIONS}

Study concept: Ali M. Fathi, Writing the original draft: Ali Ismael Sulaiman and Saad H. Murad; Data collection: Data analysis: Ali Ismael Sulaiman, and Saad H. Murad, Reviewing the final edition: All authors.

DISCLOSURE STATEMENT: The authors report no conflict of interest.

\section{ACKNOWLEDGEMENTS}

We thank the anonymous referees for their useful suggestions.

\section{REFERENCES}

Alrasheedy, A., Abdulsalim, S., Farooqui, M., Alsahali, S., Godman, B. (2021) Knowledge, Attitude and Practice About Coronavirus Disease (COVID-19) Pandemic and Its Psychological Impact on Students and Their Studies: A Cross-Sectional Study Among Pharmacy Students in Saudi Arabia, Risk Management and Healthcare Policy:14 729741

Abdullah A, Allen C. (2016). Knowledge, attitudes and behaviors of healthcare workers in the Kingdom of Saudi Arabia to MERS coronavirus and other emerging infectious diseases. Int J Environ Res Public Health; 13: 1214.

Aylie NS, Mekonen MA, Mekuria RM. (2020). The psychological impacts of COVID-19 pandemic among University Students in Bench-Sheko Zone, South-west Ethiopia: a community-based crosssectional study. Psychol Res Behav Manag.; 13:813-821. doi:10.2147/PRBM.S275593

Carlos WG, Dela Cruz CS, Cao B, Pasnick S, Jamil S. (2020) Severe acute respiratory syndrome (SARS): Knowledge, attitudes, practices and sources of information among physicians answering a SARS fever hotline service. 201(4): 7-8

CDC. Coronavirus disease 2019 (COVID-19). 2020. [Online]. Available from: https://www.cdc.gov/coronavirus/2019-

ncov/about/transmission.html [Accessed on 1st March 2020].

Khan MU, Shah S, Ahmad A, Fatokun O. (2014). Knowledge and attitude of healthcare workers about Middle East Respiratory Syndrome in multispecialty hospitals of Qassim, Saudi Arabia. BMC Public Health. 14: 1281.

Sundarasen S, Chinna K, Kamaludin K, Molly E. (2020). Psychological impact of COVID-19 and lockdown among University Students in Malaysia: implications and policy recommendations. Int J Environ Res Public Health.;17(17):6206. doi:10.3390/ijerph17176206

Sauer, L. M. (2020). What Is Coronavirus? Available online at https://www.hopkinsmedicine.org/health/conditi ons-and seases/coronavirus.

Tice AD, Kishimoto M, Dinh CH, Lam GT, Marineau M. (2016). Knowledge of severe acute respiratory syndrome among community physicians, nurses, and emergency medical responders. Prehosp Disaster Med; 21(3): 183-189.

World Health Organization. Coronavirus disease 2019 (COVID-19): [Online]. Available from: https://www.who.int/emergencies/diseases/nov el-coronavirus-2019 [Accessed on 1st March 2020]. 